\title{
Relationship between leverage and the bargaining power of labor unions: evidence from theoretical and empirical perspectives*
} La relación entre apalancamiento y poder de negociación de los sindicatos: Evidencia teórica y empírica

\author{
ChIL Sun ChOI** \\ PANDO SOHN*** \\ JI-YONG SEO $* * * *$
}

\begin{abstract}
This study examines whether a firm's leverage can be used strategically to improve its bargaining position with an organized labor union using samples of non-financial firms listed on the Korean Stock Exchange (KSE) from 1999 to 2013. Through empirical testing, we find that the portfolio with the lowest union labor coverage has the lowest leverage, while the portfolio with the highest union labor coverage has the highest leverage. We also find that collective bargaining power positively affects leverage through the regression of leverage on the bargaining power of the labor union, regardless of the analysis methods, such as static and dynamic models. With a robustness test model that used the industry adjusted labor union concentration index (IUCI), we obtain evidence that collective bargaining power positively influences leverage, which corresponds with the regression results. In conclusion, we suggest the existence of evidence
\end{abstract}

* This paper is a re-tested and revised manuscript with recent sample data based on the conceptual idea of the unpublished master's dissertation by Chil Sun Choi (2013) at Dong-A University. We thank the first author, Chil Sun Choi, for sharing his conceptual idea for the writing of this article. In addition, the authors wish to express their gratitude to the anonymous referees who provided valuable comments to improve the quality of this paper. This study was supported by research funds from Dong-A University. Professor Sohn and Professor Seo are corresponding author and co-author of this paper, respectively. Professor Sohn is responsible for the re-testing and revising of the unpublished dissertation of Choi, and Professor Seo turned the original draft in Korean into a completed manuscript in English, submitted the manuscript to the journal, and communicated with the journal's editor.

** Ph.D. Candidate in Graduate School of Business Administration, Dong-A University, 2-1, Bumin-dong, Seo-gu, Busan, 602-760, Republic of Korea (the 1st author).

*** Associate Professor in International Arbitration Department, Dong-A University, 2-1, Bumin-dong, Seo-gu, Busan, 602-760, Republic of Korea, Tel: 82-51-200-7424, E-mail: pdsohn@dau.ac.kr (corresponding author).

**** Associate Professor in Department of Business Administration, Sangmyung University, 20, Hongjimun 2-gil, Jongno-gu, Seoul, 110-743, Republic of Korea, Tel: 82-2-22875487, E-mail: jyseo@smu.ac.kr (co-author). 
demonstrating that variables related to labor unions affect leverage levels, as suggested in previous studies.

Key words: Leverage; bargaining position; union labor coverage; static and dynamic models.

JEL Classification: $G 30$, G32

\section{Resumen}

Este trabajo analiza si una firma puede utilizar estratégicamente su apalancamiento para mejorar su posición negociadora con un sindicato. Para ello se utiliza información del mercado accionario de Corea para el periodo 1999-2013, encontrando una relación creciente entre cobertura sindical y apalancamiento. También se encuentra que el mayor poder en negociaciones colectivas afecta positivamente al apalancamiento.

Palabras clave: Apalancamiento; posición negociadora; cobertura sindical; modelos estáticos y dinámicos.

Clasificación JEL: G30, G32.

\section{INTRODUCTION}

Recent financial studies on capital structure have suggested that a firm's capital structure can be affected by the nature of the interaction between its incentive structure and interested parties, such as competitors, suppliers of raw materials, and labor unions (Lewis, 1986; Bronars and Deere, 1991; DeAngelo and DeAngelo, 1991; Matsa, 2010). Studies on the relationship between labor unions and capital structure are currently of particular interest in the contemporary literature. The main finding of the studies by Klasa, Maxwell and Ortiz-Molina (2009) and Matsa (2010) is that firms have an incentive to use debt strategically in order to gain collective bargaining power in the labor union negotiation process. Matsa (2010) argues that there is a significantly negative relationship between debt financing and negotiating with a labor union. He states that firms that have militant labor unions or excess liquidity have an incentive to use capital structure to their favor when negotiating with a labor union. However, the labor union may ask to increase employee wages using any excess liquidity over and above that required for short-term debt.

Therefore, we hypothesize that firms may use much more debt to reduce the expected liquidity when they negotiate with labor unions. According to Jensen (1986), leverage can be financed to avoid investment in riskier projects. It is also plausible that another role of debt financing is to facilitate the gaining of collective bargaining power in negotiations with the labor union.

In Korea, the number of labor union strikes has increased remarkably during the last decade, which has affected the performance of Korean manufacturing firms. For example, in July 2012, the profit of Hyundai motor company was 
suffered from a labor union strike that resulted in losses of approximately USD 8 million per day. Such situations provide valuable opportunities for investigating the relationship between debt financing behavior and labor union power in Korean firms.

In light of the background of this issue, we develop theoretical methodology and build testable hypotheses to empirically test whether firms in the emerging market in Korea strategically use debt financing to gain collective bargaining power when negotiating with labor unions. The time span studied was from 1999, when the International Monetary Fund (IMF) bailout loan occurred, to 2012, when Hyundai announced a labor strike. Unlike recent studies of U.S. firms, studies about the relationship between capital structure and negotiations with labor unions in the emerging Korean market are scarce. Therefore, the present research can contribute to future studies of various emerging markets and to the development of a capital structure theory in the fields of financial economics and finance.

The contributions of this paper are as follows. First, another factor affecting the debt policy of Korean firms has been found in capital structure theory. This implies that debt policy is an important factor that has not yet been recognized by either insiders or outsiders. Second, we try to find evidence of the leverage and bargaining power of labor unions in Korea. Third, we develop a new measure for calculating the concentration of labor union power and determining the robustness of the empirical results.

The remainder of this paper is organized as follows. Section 2 presents the results of previous studies. Section 3 contains a description of the theoretical framework. In Section 4, the data and empirical models are discussed, and basic statistics are given in Section 5. Section 6 consists of the conclusion.

\section{Previous Literature}

The research dealing with the relationship between capital structure and labor unions is presented in this section. The issue is extremely controversial in the analysis of such relationships because there are contradictory results concerning the relationship between a firm's decisions about capital structure and a labor union's bargaining power. Some studies, such as those by Bronars and Deere (1991), DeAngelo and DeAngelo (1991), and Myers and Saretto (2010) argue that there is a positive relationship. From these studies, we infer that the strategic incentive resulting from negotiations with a labor union may affect a firm's financing decisions. However, Graham and Harvey (2001) and Lee and Mas (2012) argue that there is a negative or limited relationship between capital structure and labor union negotiating power. Therefore, the goal of our study is to tackle the contradictory results presented by Bronars and Deere (1991).

Bronars and Deere (1991) show that a significantly positive relationship exists between leverage and labor unions, using union coverage as a proxy variable. However, their study has a limitation in the form of an endogeneity problem between leverage and union coverage because it considers sample data at the industry level rather than at the firm level. In addition, their study omits necessary variables. Thus, long-standing and profitable firms or industries will have higher union coverage; the factors of age and profit may result in an 
increased capacity to use debt financing. Therefore, the present paper resolves the endogeneity problem between leverage and union coverage that existed in the previous research of Bronars and Deere (1991) by using firm-level data and a new measure of union coverage.

DeAngelo and DeAngelo (1991) argue that firms with labor unions tend to report in such a way as to make their earnings appear lower before negotiating with the labor unions than do firms without labor unions. They imply that this behavior may be related to the strategy a firm uses to make its employees recognize the firm's position in the competitive market.

Myers and Saretto (2010) empirically study how leverage affects negotiations between a firm and a labor union and suggest that labor unions tend to go on strike during negotiations if their leverage decreases. They also find that firms tend to increase leverage by issuing debt and repurchasing stock in response to a labor union strike. However, the evidence for increasing debt financing occurs when the labor union's strike is successful. Therefore, the evidence is in line with the previous studies that found that firms tend to increase debt financing to obtain collective bargaining power when negotiating with labor unions.

Chen et al. (2011) state that employees' collective bargaining power is positively related with firms' equity costs. We can infer that a firm's cost of equity results in increased debt financing as a lower cost financing method. Chen et al. (2011) suggest that a labor union's activity affects the firm's cost of equity. Thus, a firm with higher union coverage has a significantly higher cost of equity, regardless of adding the omitted and control variables. In particular, the premium for union coverage is higher if the labor union's bargaining power is stronger. The premium for union coverage is countercyclical; thus, the premium is lower when the business cycle is better or higher when the business cycle is otherwise.

In a recent study, Matsa (2010) analyzes whether the collective bargaining power of a labor union affects the firm's capital structure decisions by considering the changes in labor law data per U.S. state and suggests that the collective bargaining power of a labor union increases financial leverage. In addition, this study finds evidence that a firm with higher earnings volatility is more greatly influenced by the collective bargaining power of a labor union.

In terms of Korea, we considered the unpublished dissertation by Choi (2013). We thus use more recent sample data and re-test it to confirm the robustness of analytic results of Choi (2013). We will attempt to test it with extended sample period in order to identify the relationship between a labor union's bargaining power and a firm's leverage.

\section{THEORETICAL FRAMEWORK}

To analyze the relationship between the collective bargaining power of a labor union and leverage, we test whether higher earnings volatility leads to a reduction in the collective bargaining power of a labor union. Therefore, the relationship between earnings volatility and strategic leverage policy is analyzed using a model suggested by Holmstrom and Tirole (1996) that determines a firm's capital structure. 
As the conceptual idea for a theoretical framework based on Baldwin (1983) and Grout (1984), we can use the value of the general Nash equilibrium if a firm pursues the maximization of the shareholders' value, if the labor union pursues the maximization of profit, and if the bargaining power between the labor union and the manager is between $\alpha \in[0,1]$ and $(1-\alpha)$. This value is a reduced form of the negotiation game, as follows. In equation (1), $w(r), r$, and $D t$ indicate a wage arrived at via collective negotiation, the return on a risky asset, and debt.

However, a wage resulting from a consensus between the manager and the labor union tends to increase according to the bargaining power of the labor union and tends to increase or decrease depending on the intermediate stage or debt level. The labor union therefore encounters difficulty in maintaining the wage level desired by employees if non-labor costs and excessive debt increase. When there is a continuous margin on a project is available, the labor union has zero surplus value and the wage equals zero under the condition that $r$ is the same as $D t$.

$$
w(r)=\alpha(r-D t)
$$

Accordingly, maximization of the firm's value is linked to determine the financial leverage to maximize the shareholders' profit. This relationship can be logically represented by the following equation. In equation (2), the first term is equal to the cash flow at $t=0$ by issuing debt. The second term is equal to the total expected profit at $\mathrm{t}=1$ and $\mathrm{t}=2$, meaning the net wages paid to employees after negotiations between the manager and the labor union. The value of equation (2) is as follows. $E[\tilde{R}]$ means the expected profit from continuous business activity in equation (2). Thus, the optimal debt policy of a firm is determined by a tradeoff relationship between the surplus produced by $E[\tilde{R}]$ and $\alpha(r-D t)$. A firm will choose $D t=\bar{r}-\sigma$, reducing earnings volatility if the bargaining power of the labor union and earnings volatility are lower than the expected profit from continuous business activity, $\alpha \leq E[\tilde{R}] / 2 \sigma$, and vice versa.

$$
\begin{aligned}
& \underset{D t \geq D t}{\operatorname{Max}}\left[\int_{\bar{r}-\sigma}^{D t} r \frac{1}{2 \sigma} d r+\int_{D t}^{\bar{r}+\sigma} D t \frac{1}{2 \sigma} d r\right]+\int_{D t}^{\bar{r}+\sigma}((1-\alpha)(r-D t)+E[\tilde{R}]) \frac{1}{2 \sigma} d r \\
& D t^{*}=\max \left\{\underset{-}{\left.D t, \bar{D} t-\frac{E[\tilde{R}]}{\alpha}\right\}}\right. \\
& D t=\bar{r}-\sigma \bar{D} t=\bar{r}+\sigma
\end{aligned}
$$

Two logical implications can be derived from the theoretical model of the optimal debt policy of a firm from equation (2). First, the collective bargaining power of a labor union leads to an increase in the firm's debt level. The labor union's higher bargaining power allows the firm to determine debt over $D t$, , and then the optimal debt level will be increased according to the bargaining power of the labor union. Second, the collective bargaining power results in 
increasing the debt level of a firm with higher earnings volatility. The latent costs of financial distress will reduce the firm's leverage when the collective bargaining power of the labor union is lower and the volatility of the future cash flow is increased.

From a logical point of view, we need to understand the interaction between the labor union's collective bargaining power and earnings volatility in order to verify whether a firm is using debt strategically.

\section{DATA AND EMPIRICAL MODELS}

In this paper, we use sample data from Korean firms listed on the Korean Stock Exchange from 1999 to 2013. The data sources are FnGuide, the Kis Value database, and Dart, a financial database of firms listed by a Korean financial supervisory service.

We select the final sample data using four filtering procedures. First, we exclude firms with an impairment of capital and workout firms. Second, we exclude financial firms. Third, we exclude firms that do not settle accounts in December. Fourth, we exclude firms with no data on labor unions, including firms with outliers at a 5 percentile and also over $100 \%$ of leverage level. Ultimately, our sample included 266 firms.

In this study, we use union coverage as the proxy variable for the collective bargaining power of a labor union at the firm level by using static and dynamic models as empirical test models.

At first, we set up a static model, including unionization rate per industry and a proxy variable for the collective bargaining power of the labor union, to understand the relationship between leverage and collective bargaining power, as follows in equation (3). Using equation (3), we try to find evidence that debt financing is being used as a strategic method in negotiations with labor unions. We expect that the collective bargaining power of a labor union will positively and significantly affect the leverage level.

$$
\text { Leverage }_{i, t}=\alpha+\beta_{1} \text { UPower }_{i, t}+\sum \beta_{2} X_{i, t}+e_{i, t}
$$

$$
\begin{aligned}
\text { Leverage } & =\text { Total debts } \div \text { Total assets } \\
\text { UPower } & =\text { Labor union bargaining power } \\
& =\text { Number of member of labor union } \div \text { Number of total workers } \\
& =\text { vector of control variables }
\end{aligned}
$$

To prove this hypothesis that there is a strategic incentive to increase debt by earnings volatility, we set up the following equation (4). We try to confirm an interaction effect between the collective bargaining power of a labor union and earnings volatility.

In equation (4), we expect that the variable representing the collective bargaining power and earnings volatility, UPower $\times$ Volatility, will be significantly positive. $\mathrm{X}$ is used as a control variable vector, such as a non-current asset ratio (tangibility), market-to-book ratio (MB), size, and return on asset (ROA), that may affect leverage. 
(4) Leverage $_{i, t}=\alpha+\beta_{1}$ UPower $_{j, t}+\beta_{2}$ Volatility $_{i, t}+\beta_{3}(\text { UPower } \times \text { Volatility })_{i, t}$

$$
+\sum X_{i, t}+e_{i, t}
$$

Leverage $=$ Total debts $\div$ Total assets

UPower $=$ Labor union bargaining power

$=$ Number of member of labor union $\div$ Number of total workers

$\mathrm{X}=$ vector of control variables

Meanwhile, we must estimate the target leverage using an observed leverage model (5) to establish a dynamic model (partial adjustment model). We set it up according to the methods of Faulkender and Petersen (2006), Flannery and Rangan (2006), and Lemmon et al. (2008).

$$
\text { Leverage }_{i, t}=\beta X_{i, t}+e_{i, t}
$$

Leverage $_{i, t}=$ Total debts/Total assets

$X_{i, t}=$ Vector of firm characteristics

Using equation (5), we find the target leverage by using an estimated coefficient through regression. Based on previous studies (Rajan and Zingales, 1995; Flannery and Rangan, 2006), we use the X vector, including firm size (size), tangibility of asset (tangibility), market-to-book ratio (MB), and return on asset (ROA).

However, there is a difference between the current optimal capital structure and the future capital structure because of the costs needed to adjust the capital structure. In terms of conceptual logic, we set up equation (6).

$$
L_{i, t}-L_{i, t-1}=\alpha+\lambda\left(L_{i, t}^{*}-L_{i, t-1}\right)+e_{i, t}
$$

$\mathrm{L}=$ Leverage $=$ Total debts/Total assets

$\lambda=$ Adjustment speed

$\mathrm{L}^{*}=$ Target leverage

After the arrangement of equation (6) and inserting equation (5) into equation (6), we are able to derive a standardized dynamic leverage model, equation (7). Eventually, we add union coverage, earnings volatility, and an interaction term between union coverage and earnings volatility suggested by equation (8) and (9), respectively to the equation (7).

$$
\begin{gathered}
L_{i, t}=\alpha+(1-\lambda) L_{i, t-1}+\lambda L_{i, t}^{*}+e_{i, t} \\
L_{i, t}=\alpha+(1-\lambda) L_{i, t-1}+\gamma \text { UPower }_{i, t}+\sum_{i=1}^{N} \beta_{i} X_{i, t}+e_{i, t}
\end{gathered}
$$




$$
\begin{gathered}
L_{i, t}=\alpha+(1-\lambda) L_{i, t-1}+\gamma_{1} \text { UPower }_{i, t} \\
+\gamma_{2}\left(\text { UPower } \times{\text { Volatility })_{i, t}}+\sum_{i=1}^{N} \beta_{i} X_{i, t}+e_{i, t}\right.
\end{gathered}
$$

\section{EMpirical Results}

\subsection{Basic statistics}

Table 1 shows the basic statistics for the variables used in this paper. The mean value of union coverage and the mean value of the IUCI are 0.517 and 2.563 , respectively. The leverage mean is 0.495 .

TABLE 1

BASIC STATISTICS

\begin{tabular}{|lrrrr|}
\hline Variables & Mean & S.D. & Minimum & Maximum \\
\hline Union coverage & 0.517 & 0.226 & 0.004 & 0.946 \\
IUCI & 2.563 & 1.436 & 0.572 & 5.164 \\
Leverage & 0.495 & 0.207 & 0.053 & 0.999 \\
Tangibility & 0.586 & 0.162 & 0.132 & 0.946 \\
Size & 19.389 & 1.387 & 15.786 & 24.194 \\
ROA & 0.039 & 0.134 & -0.993 & 1.362 \\
MB (Market-to-Book ratio) & 0.901 & 0.387 & 0.235 & 4.816 \\
Volatility & 0.042 & 0.026 & 0.000 & 0.334 \\
\hline
\end{tabular}

Table 2 shows union coverage per industry. These statistics are in line with the results of Klasa, Maxwell, and Ortiz-Molina (2009) and Matsa (2010), who studied firms in the U.S. The highest union coverage is in the area of transportation equipment, with a mean of $63.4 \%$, and the lowest union coverage is in medicine, with a mean of $24.7 \%$.

Table 3 shows the portfolio results based on the collective bargaining power of the labor union. The portfolios are constructed as five portfolios based on union coverage. We regard higher bargaining power as higher union coverage. The union coverage and the leverage of the portfolio with the lowest bargaining power have means of 0.1672 and of 0.4826 . The union coverage and the leverage of the portfolio with the highest bargaining have means of 0.7364 and of 0.5619 . Through these statistics, we can suggest that the t-test results show a significant difference between the leverage of the portfolio with the highest bargaining power and that of the portfolio with the lowest bargaining power. The $t$-value is 3.27 and the median score value is 3.61 , with a $1 \%$ significance level.

This supports the hypothesis that an incentive for debt financing exists in the collective bargaining power of the labor union because the leverage mean and median increase with higher collective bargaining power. 
TABLE 2

UNION COVERAGE FOR EACH INDUSTRY

\begin{tabular}{|lcc|}
\hline Industry & Mean & Median \\
\hline Medicine & 0.247 & 0.231 \\
Food and beverage & 0.336 & 0.294 \\
Textile and clothing & 0.425 & 0.398 \\
Chemistry & 0.491 & 0.481 \\
Transportation equipment & 0.634 & 0.692 \\
Machinery & 0.518 & 0.541 \\
Non-metallic minerals & 0.514 & 0.497 \\
Electrical and electronics & 0.526 & 0.562 \\
Manufacturing & 0.567 & 0.573 \\
Steel and metal & 0.583 & 0.599 \\
Paper and wood & 0.621 & 0.651 \\
Others & 0.491 & 0.572 \\
\hline
\end{tabular}

Note: Industry classification is based on Korean Standard Industry Classification (KSIC) at $9^{\text {th }}$ middle classification and KSE classification.

TABLE 3

PORTFOLIO ANALYSIS

\begin{tabular}{|lccccccc|}
\hline & Lowest & 2 & 3 & 4 & Highest & $\begin{array}{c}\text { t-test, } \\
\text { Median } \\
\text { Score } \\
\text { Test }\end{array}$ \\
\hline Union coverage mean & 0.1672 & 0.3942 & 0.5439 & 0.6543 & 0.7364 & \\
Leverage mean & $(0.1604)$ & $(0.3921)$ & $(0.5202)$ & $(0.6401)$ & $(0.7316)$ & \\
& 0.4826 & 0.4891 & 0.5249 & 0.5425 & 0.5619 & $3.27 * * *$ \\
& $(0.4684)$ & $(0.4762)$ & $(0.5013)$ & $(0.5025)$ & $(0.5335)$ & $3.61 * * *$ \\
\hline
\end{tabular}

Note: $* * *$ is significant at $1 \%$ level. ( ) indicates median value.

\subsection{Regression results}

We apply a regression method after controlling for these variables to understand how the collective bargaining power of a labor union affects the leverage level. Table 4 shows the regression results using an empirical model based on equation (3). The coefficient value of union coverage is 0.1193 with a $1 \%$ significance level in Model 1, which does not control for firm characteristics. In Model 2, which does control for firm characteristics, we find that the coefficient value of union coverage is 0.1261 with a $1 \%$ significance level, as in Model 1 . In the case of Models 3 and 4, which are considered fixed effect models, we find that the coefficient values for union coverage are positively significant, with a $5 \%$ significance level, as in Models 1 and 2 using pooled ordinary least squares (OLS). This supports the results of previous studies on U.S. firms conducted by Klasa, Maxwell, and Ortiz-Molina (2009) and Matsa (2010). 
TABLE 4

UNION COVERAGE EFFECT ON LEVERAGE IN STATIC MODEL

\begin{tabular}{|lccccc|}
\hline & \multicolumn{2}{c}{ Pooled OLS } & & \multicolumn{2}{c|}{ Fixed Effect Model } \\
\cline { 2 - 3 } \cline { 5 - 6 } & Model 1 & Model 2 & & Model 3 & Model 4 \\
\hline Intercept & $0.4362 * * *$ & 0.0309 & & $0.4829 * * *$ & $0.6184 * *$ \\
& $(67.03)$ & $(0.58)$ & & $(21.02)$ & $(2.27)$ \\
Union coverage & $0.1193 * * *$ & $0.1261 * * *$ & & $0.0912 * *$ & $0.0627 * *$ \\
& $(4.92)$ & $(4.98)$ & & $(2.05)$ & $(2.24)$ \\
Tangibility & & $0.0927 * *$ & & & $0.0376 * * *$ \\
& & $(2.84)$ & & & $(2.92)$ \\
MB & & $0.1969 * * *$ & & & $0.0562 * * *$ \\
& & $(14.92)$ & & & $(3.94)$ \\
Size & & $0.0137 * * *$ & & & -0.010 \\
& & $(2.86)$ & & & $(-0.72)$ \\
ROA & & $-0.4018 * * *$ & & & $-0.1954 * * *$ \\
& & $(-8.93)$ & & & $(-5.97)$ \\
Time effect & & & & Yes & Yes \\
Firm effect & & & & Yes & Yes \\
Industry effect & Yes & Yes & & Yes & Yes \\
Adj. $\mathrm{R}^{2}$ & 0.018 & 0.192 & & 0.018 & 0.099 \\
F-value & $24.82 * * *$ & $69.36 * * *$ & & $14.92 * * *$ & $12.09 * * *$ \\
\hline
\end{tabular}

Note: ( ) is t-value based on the Newey-West standard error. *** and ** are significant at the $1 \%$ and $5 \%$ level, respectively.

As shown in Table 5, we use equation (4) to confirm the findings of Matsa (2010). Using a pooled OLS and fixed effect models, Model 1 and Model 3 (without controlling for firm characteristics) and Model 2 and Model 4 (controlling for firm characteristics), show that the coefficient values of the interaction term between union coverage and earnings volatility are significant. This is in line with the previous study by Matsa (2010) in that the leverage level of a firm tends to increase with union coverage and earnings volatility.

Based on equation (8), Table 6 shows that the coefficient values of union coverage are positive at the $1 \%$ and $5 \%$ significance levels according to the results of Model 1 and Model 2. We also find the same results from Model 3 and Model 4 when using a fixed effect model. Therefore, we confirm that leverage increases when the collective bargaining power of a labor union is high, considering the speed of leverage adjustment.

Table 7 shows the test results using the dynamic model based on equation (9) and considering the interaction term between bargaining power and earnings volatility. In this test, we consider two estimation methods-Sys-GMM and a fixed effect model.

According to Table 7, there is evidence that the coefficient values of the interaction term, Union*EarnginV, are positive at the 5\% significance level regardless of model. Thus, we understand that the collective bargaining power of a labor union positively affects the leverage level via the interaction of bargaining power and earnings volatility. 
TABLE 5

UNION COVERAGE AND INTERACTION EFFECT ON LEVERAGE IN STATIC MODEL

\begin{tabular}{|c|c|c|c|c|}
\hline & \multicolumn{2}{|c|}{ Pooled OLS } & \multicolumn{2}{|c|}{ Fixed Effect Model } \\
\hline & Model 1 & Model 2 & Model 3 & Model 4 \\
\hline Intercept & $\begin{array}{l}0.5012 * * * \\
(33.04)\end{array}$ & $\begin{array}{r}0.0301 \\
(0.45)\end{array}$ & $\begin{array}{l}0.4527 * * * \\
(21.69)\end{array}$ & $\begin{array}{r}0.4819 \\
(1.59)\end{array}$ \\
\hline Union coverage & $\begin{array}{l}0.1104 * * * \\
(4.02)\end{array}$ & $\begin{array}{l}0.1101 * * * \\
(3.98)\end{array}$ & $\begin{array}{l}0.0812 * * * \\
(2.89)\end{array}$ & $\begin{array}{l}0.0729 * * \\
(2.46)\end{array}$ \\
\hline (Union) x (Volatility) & $\begin{array}{l}0.4292 * * \\
(2.36)\end{array}$ & $\begin{array}{l}0.2754 * * * \\
(3.98)\end{array}$ & $\begin{array}{l}0.7792 * * * \\
(3.82)\end{array}$ & $\begin{array}{l}0.7529 * * * \\
(3.16)\end{array}$ \\
\hline Tangibility & & $\begin{array}{l}0.0934 * * * \\
(2.64)\end{array}$ & & $\begin{array}{r}0.0389 \\
(0.83)\end{array}$ \\
\hline MB & & $\begin{array}{l}0.1908 * * * \\
(14.14)\end{array}$ & & $\begin{array}{l}0.0516 * * * \\
(3.89)\end{array}$ \\
\hline Size & & $\begin{array}{l}0.0116 * * * \\
(2.98)\end{array}$ & & $\begin{array}{r}-0.0065 \\
(-0.36)\end{array}$ \\
\hline ROA & & $\begin{array}{c}-0.3984 * * * \\
(-8.67)\end{array}$ & & $\begin{array}{l}-0.2146 * * * \\
(-6.43)\end{array}$ \\
\hline Time effect & & & Yes & Yes \\
\hline Firm effect & & & Yes & Yes \\
\hline Industry effect & Yes & Yes & Yes & Yes \\
\hline Adj. $\mathrm{R}^{2}$ & 0.018 & 0.195 & 0.018 & 0.129 \\
\hline F-value & $13.09 * * *$ & $54.06 * * *$ & $8.09 * * *$ & $11.58 * * *$ \\
\hline
\end{tabular}

Note: ( ) is t-value based on the Newey-West standard error. *** and ** are significant at the $1 \%$ and $5 \%$ level, respectively.

TABLE 6

UNION COVERAGE EFFECT ON LEVERAGE IN DYNAMIC MODEL

\begin{tabular}{|c|c|c|c|c|}
\hline & \multicolumn{2}{|c|}{$\begin{array}{c}\text { System Dynamic (GMM) } \\
\text { (Arellano-Bover/ } \\
\text { Blundell-Bond) }\end{array}$} & \multicolumn{2}{|c|}{ Fixed Effect Model } \\
\hline & Model 1 & Model 2 & Model 3 & Model 4 \\
\hline Intercept & $\begin{array}{c}0.2025 * * * \\
(6.84)\end{array}$ & $\begin{array}{l}1.4895 * * * \\
(5.69)\end{array}$ & $\begin{array}{l}0.1992 * * * \\
(6.59)\end{array}$ & $\begin{array}{l}2.5752 * * * \\
(7.93)\end{array}$ \\
\hline Leverage $_{(\mathrm{t}-1)}$ & $\begin{array}{l}0.3984 * * * \\
(16.79)\end{array}$ & $\begin{array}{l}0.5249 * * * \\
(30.28)\end{array}$ & $\begin{array}{l}0.6939 * * * \\
(25.85)\end{array}$ & $\begin{array}{l}0.6284 * * * \\
(35.48)\end{array}$ \\
\hline Union coverage & $\begin{array}{l}0.2152 * * * \\
(2.94)\end{array}$ & $\begin{array}{l}0.0928 * * \\
(2.42)\end{array}$ & $\begin{array}{l}0.0904 * * * \\
(3.05)\end{array}$ & $\begin{array}{l}0.0682 * * \\
(2.25)\end{array}$ \\
\hline Tangibility & & $\begin{array}{r}0.0427 \\
(0.86)\end{array}$ & & $\begin{array}{r}0.0346 \\
(0.92)\end{array}$ \\
\hline MB & & $\begin{array}{l}0.0572 * * * \\
(3.93)\end{array}$ & & $\begin{array}{l}0.0924 * * * \\
(7.69)\end{array}$ \\
\hline Size & & $\begin{array}{l}0.0904 * * * \\
(5.82)\end{array}$ & & $\begin{array}{l}0.1285 * * * \\
(7.93)\end{array}$ \\
\hline ROA & & $\begin{array}{l}-0.9655 * * * \\
(-26.87)\end{array}$ & & $\begin{array}{l}-0.9027 \\
(-26.89)\end{array}$ \\
\hline Time effect & Yes & Yes & Yes & Yes \\
\hline Firm effect & Yes & Yes & Yes & Yes \\
\hline Industry effect & Yes & Yes & Yes & Yes \\
\hline $\begin{array}{l}\text { Adj.R }{ }^{2} \\
\text { Wald } \chi^{2}\end{array}$ & $290.46 * * *$ & $1534.29 * * *$ & 0.602 & 0.765 \\
\hline F-value & & & $301.81 * * *$ & $335.59 * * *$ \\
\hline
\end{tabular}

Note: $* * *$ and $* *$ are significant at the $1 \%$ and $5 \%$ level, respectively. 
TABLE 7

UNION COVERAGE AND INTERACTION EFFECT ON LEVERAGE IN DYNAMIC MODEL

\begin{tabular}{|c|c|c|c|c|}
\hline & \multicolumn{2}{|c|}{$\begin{array}{c}\text { System Dynamic (GMM) } \\
\text { (Arellano-Bover/ } \\
\text { Blundell-Bond) }\end{array}$} & \multicolumn{2}{|c|}{ Fixed Effect Model } \\
\hline & Model 1 & Model 2 & Model 3 & Model 4 \\
\hline Intercept & $\begin{array}{l}0.0988 * * * \\
(2.92)\end{array}$ & $\begin{array}{l}-1.6842 * * * \\
(-7.62)\end{array}$ & $\begin{array}{l}0.2628 * * * \\
(9.25)\end{array}$ & $\begin{array}{l}-1.8992 * * * \\
(-7.92)\end{array}$ \\
\hline Leverage (t-1) & $\begin{array}{l}0.8567 * * * \\
(20.82)\end{array}$ & $\begin{array}{l}0.7649 * * * \\
(22.57)\end{array}$ & $\begin{array}{l}0.6004 * * * \\
(20.03)\end{array}$ & $\begin{array}{l}0.6352 \text { *** } \\
(25.14)\end{array}$ \\
\hline Union coverage & $\begin{array}{l}0.0732 * * \\
(2.65)\end{array}$ & $\begin{array}{l}0.0461 * * * \\
(2.89)\end{array}$ & $\begin{array}{l}0.0586 * * \\
(2.36)\end{array}$ & $\begin{array}{l}0.0302 * * * \\
(2.67)\end{array}$ \\
\hline (IUCI) x (Volatility) & $\begin{array}{l}0.7348 * * \\
(2.43)\end{array}$ & $\begin{array}{l}0.2827 * * \\
(2.25)\end{array}$ & $\begin{array}{l}0.2248 * * \\
(2.19)\end{array}$ & $\begin{array}{l}0.1863 * * \\
(2.02)\end{array}$ \\
\hline Tangibility & & $\begin{array}{r}-0.0429 \\
(-0.73)\end{array}$ & & $\begin{array}{r}0.0085 \\
(0.27)\end{array}$ \\
\hline MB & & $\begin{array}{l}0.0325 * * \\
(1.98)\end{array}$ & & $\begin{array}{r}0.0102 \\
(0.99)\end{array}$ \\
\hline Size & & $\begin{array}{l}0.0924 * * * \\
(7.81)\end{array}$ & & $\begin{array}{l}0.1159 * * * \\
(8.76)\end{array}$ \\
\hline ROA & & $\begin{array}{l}-0.7293 * * * \\
(-18.46)\end{array}$ & & $\begin{array}{l}-0.5739 * * * \\
(-17.09)\end{array}$ \\
\hline Time effect & Yes & Yes & Yes & Yes \\
\hline Firm effect & Yes & Yes & Yes & Yes \\
\hline Industry effect & Yes & Yes & Yes & Yes \\
\hline Adj.R2 & & & 0.497 & 0.826 \\
\hline Wald $\chi^{2}$ & $428.97 * * *$ & $900.64 * * *$ & & \\
\hline F-value & & & $134.84 * * *$ & $129.57 * * *$ \\
\hline
\end{tabular}

Note: $* * *$ and $* *$ are significant at the $1 \%$ and $5 \%$ level, respectively.

\subsection{Robustness test}

We use the IUCI instead of union coverage. Therefore, we develop the IUCI and consider it an appropriate proxy variable for the bargaining power of a labor union because the variation attributed to a difference in industry is removed. The IUCI estimation method is as follows. We establish the following models (11), (12), (13), and (14) as the empirical models using IUCI.

$$
I U C I=\sum_{i=1}^{N}\left(w_{i, j, t}-E(w)_{j, t}\right)^{2}
$$

$E[w]_{j, t}=$ average ratio of union members in $\mathrm{j}$ industry to all industries at time $\mathrm{t}$ $w_{i, j, t}=$ ratio of union members in firm $\mathrm{i}$ in industry $\mathrm{j}$ at time $\mathrm{t}$ 


$$
\begin{gathered}
L_{i, t}=\alpha+\beta_{1} I U C I_{i, t}+\sum_{i=1}^{N} \gamma_{i} X_{i, t}+e_{i, t} \\
L_{i, t}=\alpha+\beta_{1} I U C I_{i, t}+\beta_{2}\left(I U C I \cdot \text { Volatility }_{i, t}+\sum_{i=1}^{N} \gamma_{i} X_{i, t}+e_{i, t}\right. \\
L_{i, t}=\alpha+(1-\lambda) L e v_{i, t-1}+\gamma I U C I_{i, t}+\sum \beta_{i} X_{i, t}+e_{i, t} \\
L_{i, t}=\alpha+(1-\lambda) L_{i, t-1}+\gamma_{1} I U C I_{i, t}+\gamma_{2}\left(I U C I \cdot \text { Volatility }_{i, t}+\sum \beta_{i} X_{i, t}+e_{i, t}\right.
\end{gathered}
$$

Table 8 shows the analytic results of equation (11) with the IUCI tested by a pooled OLS and a fixed effect model. In Table 8, we find that the coefficient value of IUCI is positive at a $1 \%$ significance level regardless of model type.

TABLE 8

IUCI EFFECT ON LEVERAGE IN STATIC MODEL

\begin{tabular}{|lcccccc|}
\hline & \multicolumn{2}{c}{ Pooled OLS } & & \multicolumn{2}{c|}{ Fixed Effect Model } \\
\cline { 2 - 3 } \cline { 5 - 6 } & Model 1 & Model 2 & & Model 3 & Model 4 \\
\hline Intercept & $0.5892 * * *$ & $0.2942 * * *$ & & $0.7029 * * *$ & 0.4028 \\
& $(41.02)$ & $(3.67)$ & & $(17.94)$ & $(1.03)$ \\
IUCI & $0.0192 * * *$ & $0.0188 * * *$ & & $0.0728 * * *$ & $0.0659 * * *$ \\
& $(5.24)$ & $(4.28)$ & & $(4.25)$ & $(4.69)$ \\
Tangibility & & $0.2476 * * *$ & & & $0.2398 * * *$ \\
& & $(4.84)$ & & & $(3.69)$ \\
MB & & $0.3482 * * *$ & & & $0.2135 * * *$ \\
& & $(7.54)$ & & & $(12.94)$ \\
Size & & -0.0069 & & & -0.0008 \\
& & $(-0.84)$ & & & $(-0.06)$ \\
ROA & & $-0.6925 * * *$ & & & $-0.6028 * * *$ \\
& & $(-4.96)$ & & & $(-13.92)$ \\
Time effect & & & & Yes & Yes \\
Firm effect & & & & Yes & Yes \\
Industry effect & Yes & Yes & & Yes & Yes \\
Adj. $\mathrm{R}^{2}$ & 0.010 & 0.293 & & 0.008 & 0.397 \\
F-value & $18.03 * * *$ & $28.29 * * *$ & & $4.49 * *$ & $78.98 * * *$ \\
\hline
\end{tabular}

Note: ( ) is t-value based on the Newey-West standard error. *** and ** are significant at the $1 \%$ and $5 \%$ level, respectively.

Table 9 shows the results using equation (12) as the static model. In Table 9, we find that the interaction between bargaining power and earnings volatility positively affects leverage at a significant level. More specifically, the coefficient value of IUCI*Volatility positively affects leverage at a $1 \%$ significance level 
regardless of model type. Therefore, we confirm that the previous test results using union coverage are reliable and without bias.

TABLE 9

IUCI AND INTERACTION EFFECT ON LEVERAGE IN STATIC MODEL

\begin{tabular}{|c|c|c|c|c|}
\hline & \multicolumn{2}{|c|}{ Pooled OLS } & \multicolumn{2}{|c|}{ Fixed Effect Model } \\
\hline & Model 1 & Model 2 & Model 3 & Model 4 \\
\hline Intercept & $\begin{array}{l}0.5026 * * * \\
(42.06)\end{array}$ & $\begin{array}{r}0.0508 \\
(0.84)\end{array}$ & $\begin{array}{l}0.5238 * * * \\
(20.16)\end{array}$ & $\begin{array}{c}0.5608 * * \\
(2.05)\end{array}$ \\
\hline IUCI & $\begin{array}{c}0.0245 * * * \\
(4.09)\end{array}$ & $\begin{array}{c}0.0137 * * * \\
(2.99)\end{array}$ & $\begin{array}{c}0.0203 * * * \\
(2.63)\end{array}$ & $\begin{array}{c}0.0159 * * \\
(2.40)\end{array}$ \\
\hline (IUCI) x (Volatility) & $\begin{array}{c}0.9908 * * * \\
(3.27)\end{array}$ & $\begin{array}{c}0.8124 * * * \\
(2.94)\end{array}$ & $\begin{array}{c}0.8965 * * * \\
(3.84)\end{array}$ & $\begin{array}{c}0.7682 * * * \\
(3.46)\end{array}$ \\
\hline Tangibility & & $\begin{array}{l}0.1421 * * * \\
(3.92)\end{array}$ & & $\begin{array}{r}0.0406 \\
(0.99)\end{array}$ \\
\hline MB & & $\begin{array}{l}0.1948 \text { *** } \\
(13.09)\end{array}$ & & $\begin{array}{c}0.0482 * * * \\
(3.67)\end{array}$ \\
\hline Size & & $\begin{array}{c}0.02025 * * * \\
(3.69)\end{array}$ & & $\begin{array}{r}-0.0072 \\
(-0.53)\end{array}$ \\
\hline ROA & & $\begin{array}{c}-0.4014 \text { *** } \\
(-8.89)\end{array}$ & & $\begin{array}{c}-0.1986 * * * \\
(-6.07)\end{array}$ \\
\hline Time effect & & & Yes & Yes \\
\hline Firm effect & & & Yes & Yes \\
\hline Industry effect & Yes & Yes & Yes & Yes \\
\hline Adj. $R^{2}$ & 0.014 & 0.199 & 0.015 & 0.126 \\
\hline F-value & $10.29 * * *$ & $54.39 * * *$ & $8.26 * * *$ & $11.81 * * *$ \\
\hline
\end{tabular}

Note: ( ) is t-value based on the Newey-West standard error. *** and ** are significant at the $1 \%$ and $5 \%$ level, respectively.

Table 10 and Table 11 show how the interaction term between bargaining power and earnings volatility affects leverage using a partial adjustment model based on equations (13) and (14).

In Table 10, we confirm that the coefficients of the IUCI in Model 1 and Model 2, based on the Sys-GMM method, are positively significant at the 5\% level regardless of model type.

Table 11 shows the interaction term effect through equation (14) by considering the partial adjustment model. From Table 11, we find significant evidence that the coefficient values of the IUCI in Model 1 and Model 2 are positively significant at the 5\% and 10\% levels, respectively. In Model 3 and Model 4, the coefficient values are positive at the $1 \%$ significance level.

\section{Conclusion}

In this study, we analyze how the collective bargaining power of a labor union affects a firm's leverage using Korean firms. To confirm the results of 
TABLE 10

IUCI EFFECT ON LEVERAGE IN DYNAMIC MODEL

\begin{tabular}{|c|c|c|c|c|}
\hline & \multicolumn{2}{|c|}{$\begin{array}{c}\text { System Dynamic (GMM) } \\
\text { (Arellano-Bover/ } \\
\text { Blundell-Bond) }\end{array}$} & \multicolumn{2}{|c|}{ Fixed Effect Model } \\
\hline & Model 1 & Model 2 & Model 3 & Model 4 \\
\hline Intercept & $\begin{array}{l}0.2601 * * * \\
(7.99)\end{array}$ & $\begin{array}{l}-1.5295 * * * \\
(-5.69)\end{array}$ & $\begin{array}{l}0.1956 * * * \\
(5.69)\end{array}$ & $\begin{array}{l}-2.2597 * * * \\
(-7.05)\end{array}$ \\
\hline Leverage $_{(\mathrm{t}-1)}$ & $\begin{array}{l}0.4006 * * * \\
(17.08)\end{array}$ & $\begin{array}{l}0.3287 * * * \\
(33.95)\end{array}$ & $\begin{array}{l}0.6594 * * * \\
(25.09)\end{array}$ & $\begin{array}{l}0.6052 * * * \\
(37.09)\end{array}$ \\
\hline IUCI & $\begin{array}{l}0.0263 * * \\
(2.35)\end{array}$ & $\begin{array}{l}0.0109 * * \\
(2.39)\end{array}$ & $\begin{array}{l}0.0028 * * \\
(2.35)\end{array}$ & $\begin{array}{l}0.0021 * * \\
(2.40)\end{array}$ \\
\hline Tangibility & & $\begin{array}{r}0.0483 \\
(0.92)\end{array}$ & & $\begin{array}{r}0.0503 \\
(0.91)\end{array}$ \\
\hline MB & & $\begin{array}{l}0.0506 * * * \\
(3.67)\end{array}$ & & $\begin{array}{l}0.0884 * * * \\
(7.01)\end{array}$ \\
\hline Size & & $\begin{array}{l}0.1035 * * * \\
(5.96)\end{array}$ & & $\begin{array}{l}0.1263 * * * \\
(7.54)\end{array}$ \\
\hline ROA & & $\begin{array}{l}-0.9839 * * * \\
(-27.81)\end{array}$ & & $\begin{array}{l}-0.8929 * * * \\
(-26.01)\end{array}$ \\
\hline Time effect & Yes & Yes & Yes & Yes \\
\hline Firm effect & Yes & Yes & Yes & Yes \\
\hline Industry effect & Yes & Yes & Yes & Yes \\
\hline $\begin{array}{l}\text { Adj.R }{ }^{2} \\
\text { Wald } \gamma^{2}\end{array}$ & $28469 * * *$ & $154392 * * *$ & 0.589 & 0.819 \\
\hline F-value & & & $299.94 * * *$ & $338.63 * * *$ \\
\hline
\end{tabular}

Note: $* * *$ and $* *$ are significant at the $1 \%$ and $5 \%$ level, respectively.

previous studies that used sample data from the U.S., we attempt to empirically test the relationship between the collective bargaining power of a labor union and leverage in order to understand whether a manager has an incentive to increase debt financing to reduce a labor union's collective bargaining power. Our study uses various empirical models, such as static and dynamic models, and considers various proxy variables for the bargaining power of a labor union to obtain robustness.

Using the Sys-GMM method to resolve the endogeneity problem of Bronars and Deere (1991), our test results provide pivotal evidence that the interaction term between the bargaining power of a labor union and earnings volatility positively affects leverage. This is in line with the findings of Chen et al. (2011) and Matsa (2010).

The theoretical framework predicts that firms adjust their leverage level when they face the bargaining power of a labor union. Accordingly, the theoretical implication is that a labor union is one of many key factors in the adjustment of leverage level. The practical implication of our study is that managers should consider the factor of labor union power when establishing financial policy and raising funds for new projects. 
TABLE 11

IUCI AND INTERACTION EFFECT ON LEVERAGE IN DYNAMIC MODEL

\begin{tabular}{|c|c|c|c|c|}
\hline & \multicolumn{2}{|c|}{$\begin{array}{c}\text { System Dynamic (GMM) } \\
\text { (Arellano-Bover/ } \\
\text { Blundell-Bond) }\end{array}$} & \multicolumn{2}{|c|}{ Fixed Effect Model } \\
\hline & Model 1 & Model 2 & Model 3 & Model 4 \\
\hline Intercept & $\begin{array}{l}0.2012 * * * \\
(9.86)\end{array}$ & $\begin{array}{l}-1.6927 * * * \\
(-8.89)\end{array}$ & $\begin{array}{l}0.2439 * * * \\
(8.67)\end{array}$ & $\begin{array}{l}-1.964 * * * \\
(-7.87)\end{array}$ \\
\hline Leverage $_{(\mathrm{t}-1)}$ & $\begin{array}{l}0.3909 * * * \\
(15.78)\end{array}$ & $\begin{array}{l}0.4639 * * * \\
(16.85)\end{array}$ & $\begin{array}{l}0.5856 \\
(20.03)\end{array}$ & $\begin{array}{l}0.5649 * * * \\
(25.67)\end{array}$ \\
\hline IUCI & $\begin{array}{l}0.0405 * * * \\
(5.93)\end{array}$ & $\begin{array}{l}0.0057 * * \\
(2.36)\end{array}$ & $\begin{array}{l}0.0046 * * \\
(1.99)\end{array}$ & $\begin{array}{l}0.0019 * * \\
(2.26)\end{array}$ \\
\hline (IUCI) x (Volatility) & $\begin{array}{c}0.4209 * \\
(1.78)\end{array}$ & $\begin{array}{l}0.1608 * * \\
(2.26)\end{array}$ & $\begin{array}{l}0.2186 * * * \\
(3.02)\end{array}$ & $\begin{array}{l}0.1792 * * * \\
(2.99)\end{array}$ \\
\hline Tangibility & & $\begin{array}{r}0.0589 \\
(1.26)\end{array}$ & & $\begin{array}{r}0.0167 \\
(0.39)\end{array}$ \\
\hline MB & & $\begin{array}{r}-0.0148 \\
(-1.47)\end{array}$ & & $\begin{array}{r}0.0086 \\
(0.92)\end{array}$ \\
\hline Size & & $\begin{array}{l}0.1126 * * * \\
(9.89)\end{array}$ & & $\begin{array}{l}0.1162 * * * \\
(8.59)\end{array}$ \\
\hline ROA & & $\begin{array}{l}-0.6458 \\
(-18.65)\end{array}$ & & $\begin{array}{l}-0.5862 * * * \\
(-17.01)\end{array}$ \\
\hline Time effect & Yes & Yes & Yes & Yes \\
\hline Firm effect & Yes & Yes & Yes & Yes \\
\hline Industry effect & Yes & Yes & Yes & Yes \\
\hline Adj. $R^{2}$ & & & 0.489 & 0.857 \\
\hline Wald $\chi^{2}$ & $314.95 * * *$ & $926.09 * * *$ & & \\
\hline F-value & & & $138.57 * * *$ & $129.84 * * *$ \\
\hline
\end{tabular}

Note: $* * *, * *$, and $*$ are significant at the $1 \%, 5 \%$, and $10 \%$ level, respectively.

The main findings of this study are as follows. We determine that the bargaining power of a labor union positively affects leverage and that the interaction term between bargaining power and earnings volatility has significant effects on leverage. In addition, we reconfirm that the bargaining power of a labor union also positively and significantly affects leverage by using a partial adjustment model, regardless of the estimation method, and including control variables. We also prove the reliability of union coverage as a proxy variable through various test methods, such as static and dynamic models, by using another variable-IUCI.

Based on our empirical results, we conclude that the bargaining power of a labor union is a key determinant in capital structure financial decisions; it also helps in the understanding of a firm manager's behavior when making financial decisions.

This paper has several limitations. First, the samples used do not cover a long period; therefore, we need to extend the sample time period. Second, it is necessary to use financial data when firms are facing a labor union strike; unfortunately, real data is not always available. A recommendation for future research is to collect data from real situations. 


\section{REFERENCES}

Baldwin, C.Y. (1983). "Productivity and Labor Unions: An Application of the Theory of Self-enforcing Contracts", Journal of Business, Vol 56; 155-185.

Bronars, S.G. and Deere, D.R. (1991). "The Threat of Unionization, the Use of Debt, and the Preservation of Shareholder Wealth", Quarterly Journal of Economics, Vol. 106; 231-254.

Chen, H.J., Kacperczyk, M. and Ortiz-M., H. (2011). "Labor Unions, Operating Flexibility, and the Cost of Equity", Journal of Financial and Quantitative Analysis, Vol. 46; 25-58.

Choi, C. S. (2013). "Capital Structure as a Strategic Role in Collective Bargaining with Labor Unions", Master's Dissertation in Dong-A University, Not published; 1-34.

DeAngelo, H. and DeAngelo, L. (1991). "Union Negotiations and Corporate Policy: A Study of Labor Concessions in the Domestic Steel Industry during the 1980s", Journal of Financial Economics, Vol. 30; 3-43.

Faulkender, M. and Petersen, M.A.(2006). "Does the Source of Capital Affect Capital Structure?", Review of Financial Studies, Vol 19; 45-79.

Flannery, M. and Rangan, K. (2006). "Partial Adjustment toward Target Capital Structures", Journal of Financial Economics, Vol. 79; 469-506.

Graham, J. R. and Harvey, C. R. (2001). "The Theory and Practice of Corporate Finance: Evidence from the Field", Journal of Financial Economics, Vol. 60; 187-243.

Grout, P. A. (1984). "Investment and Wages in the Absence of Binding Contracts: A Nash Bargaining Approach”, Econometrica, Vol. 52; 449-460.

Hölmstrom, B. and Tirole, J. (1996). "Modeling Aggregate Liquidity", American Economic Review, Vol. 86; 187-191.

Jensen, M. C. (1986). “Agency Costs of Free Cash Flow, Corporate Finance, and Takeovers", American Economic Review, Vol. 76; 323-329.

Klasa, S., Maxwell, W. F. and Ortiz-M., H. (2009). "The Strategic use of Corporate Cash Holdings in Collective Bargaining with Labor Unions", Journal of Financial Economics, Vol. 92; 421-442.

Lee, D.S. and Mas, A. (2012). "Long-run impacts of unions on firms: New evidence from financial markets, 1961-1999", Quarterly Journal of Economics, Vol. 127; 333-78.

Lemmon, M.L., Roberts, M.R. and Zender, J.F. (2008). "Back to the Beginning: Persistence and the Cross-Section of Corporate Capital Structure", Journal of Finance, Vol. 63; 1575-1608.

Lewis, H.G. (1986). Union Relative Wage Effects: A Survey, University of Chicago Press.

Matsa, D.A. (2010). "Capital Structure as a Strategic Variable: Evidence from Collective Bargaining", The Journal of Finance, Vol. 65; 1197-1232.

Myers, B.W. and Saretto, A. (2010). "Union Strikes and the Impact of Nonfinancial Stake-holders on Capital Structure", SSRN eLibrary.

Rajan, R.G. and Zingales, L. (1995). "What Do We Know About Capital Structure? Some Evidence from International Data", Journal of Finance, Vol. 50; 1421-1460. 
